Gut, 1981, 22, 933-938

\title{
Nocturnal growth hormone and gonadotrophin secretion in growth retarded children with Crohn's disease
}

\author{
M J G FARTHING,* C A CAMPBELL, J WALKER-SMITH, C R W EDWARDS, \\ L H REES, AND A M DAWSON
}

From the Departments of Gastroenterology, Endocrinology, and Child Health, St. Bartholomew's Hospital, London

SUMMARY Although impaired growth hormone secretion in response to pharmacological stimuli occurs in some growth retarded children with Crohn's disease, its relationship to past and future th is uncertain. We have therefore determined the grpppppwth hormone and gonadotrophin response to the physiological stimulus of sleep by continuous venous sampling in five severely growth is uncertain. We have therefore determined the growth hormone and gonadotrophin gonadotrophin profiles, the mean plasma hormone concentrations during the first five hours of sleep were determined. In three of the five patients, five hour mean growth hormone levels were reduced $(3.8,5 \cdot 0$, and $8.5 \mathrm{mU} / \mathrm{l})$ compared with levels reported previously in normal short children $(10-43 \mathrm{mU} / \mathrm{l})$, although the pulsatile pattern of growth hormone secretion was preserved in all. Nocturnal growth hormone secretion was unrelated to the growth velocities of these children during both pre- and post-treatment assessment periods but a significant correlation was found between growth hormone concentration and a disease activity score $(r=0.79, \mathrm{P}<0.05)$, suggesting that growth hormone release by the pituitary was influenced by the severity of the disease. Nocturnal growth hormone secretion was also correlated with gonadotrophin secretion (luteinising hormone, $r=0.99$, and follicle stimulating hormone, $r=0.96 ; \quad \mathrm{P}<0.01$ ) indicating more extensive hypothalamic-pituitary disturbance. These findings suggest that hypothalamic-pituitary function is depressed in growth retarded children with Crohn's disease, but that abnormalities of growth hormone secretion are unlikely to be directly involved in the growth retardation seen in this condition.

Severe retardation of linear growth and delayed sexual development occur in children with Crohn's disease. ${ }^{1-11}$ Growth retardation may precede the development of gastrointestinal symptoms and be unrelated to the severity of the disease. 1213

Although endocrine dysfunction 69 and nutritional deficiency 14 have been implicated as possible factors in the pathogenesis of growth retardation in Crohn's disease, the precise pathophysiological mechanisms have not been established. Impairment of growth hormone secretion in response to pharmacological stimuli occurs in some children with Crohn's disease 9 but equivocal or normal growth hormone secretion has

*Address for correspondence: Dr M J G Farthing, Tufts University School of Medicine, Department of Medicine, Division of Geographic Medicine, 136 Harrison Avenue, Boston MA 02111, USA

Received for publication 5 May 1981 been reported by others. 141517 The physiological rise in growth hormone during sleep 18 is recognised to provide a more reliable assessment of growth hormone secretion than the conventional provocation tests 1920 with which results of the former may conflict. ${ }^{20}$ Limited studies of growth hormone secretion during sleep in children with Crohn's disease determined by intermittent venous sampling have produced discordant results. 141517

To clarify these issues nocturnal growth hormone secretion in growth retarded children with Crohn's disease was assessed by continuous venous sampling and compared with the growth hormone response to insulin-induced hypoglycaemia. In addition, nocturnal growth hormone secretion was related to disease activity, pre- and post-treatment growth velocity, and 
to nocturnal gonadotrophin secretion, another index of hypothalamic-pituitary function.

\section{Methods}

\section{PATIENTS}

Five consecutive children with growth retardation due to Crohn's disease were investigated. The diagnosis was based on clinical, radiological, and histological criteria.21 Clinical details with respect to sex, age, duration of symptoms, extent of disease, sexual development, 22 and anthropometric data are shown in Table 1. All patients had marked reduction in linear growth during the year preceding the study (all were below the 3rd centile for height and weight except patient 5 who was below the 10th centile for both) and bone-age ${ }^{23}$ was delayed by at least two years. None of the patients was receiving corticosteroid therapy or had had surgery before this study. Disease activity was rated using an activity score 24 which took into account both clinical and laboratory data. The maximum theoretical score using this method is 38 , although in clinical practice scores rarely exceed 20 .

Continuous venous sampling was achieved through a teflon or silicone elastomer ${ }^{25}$ cannula in an antecubital vein, connected by polyvinyl chloride tubing and a Watson Marlowe flow inducer to an automatic sample collector. Thrombogenesis was prevented by a simultaneous, constant heparin infusion $(10000 \mathrm{IU} / \mathrm{ml})$ into the collecting system. A small dilution factor (approximately $5 \%$ ) was determined from the total volume of heparin infused and the volume of the plasma samples was corrected accordingly. Blood was collected in 20 minute aliquots between approximately 22.00 and 10.00 hours. The plasma was separated immediately and stored at $-20^{\circ} \mathrm{C}$ before analysis. Sampling was performed in a single room so that sleep was undisturbed and the periods when the child was asleep or awake were determined by continuous direct observation.

Standard insulin hypoglycaemia 26 (dose $0 \cdot 15 \mathrm{u} / \mathrm{kg}$ ) was obtained on a different day during the same admission under identical conditions of bed rest and fasting from 20.00 hours on the evening before the study.

Plasma growth hormone concentration was determined by double antibody radioimmunoassay. Growth hormone values were expressed in $\mathrm{mU} /$ litre against the First International Reference Preparation (MRC 66/217). Luteinising hormone and follicle stimulating hormone were also determined by double antibody radioimmunoassay and expressed as U/litre of MRC Standards $68 / 40$ and 78/549 respectively. All assays were subject to quality control on the Supraregional Assay Service QC Schemes.

After the growth hormone studies, patients 1, 2, and 4 were treated surgically, and patients 3 and 5 received corticosteroids. Post-treatment growth velocity was determined during the first six months follow-up. Nocturnal growth hormone secretion in these children with Crohn's disease was compared with control data obtained in normal short children reported by Howse et al,27 who used a virtually identical continuous sampling technique and the same International Reference Standard in the growth hormone assay. Informed consent was obtained from the children and their parents before entry into the study.

\section{Results}

\section{Growth hormone}

Individual nocturnal growth hormone profiles of the five patients with Crohn's disease are shown in Fig. 1. Growth hormone is secreted in a pulsatile manner, the major peaks usually occurring during the first five hours of sleep. Although peak frequency is similar in all patients, the magnitude of the peaks varies in different patients, most markedly between patients 1 and 5 . A convenient method of comparing the growth hormone response to sleep in different subjects is by determining the nocturnal mean growth hormone concentrations during the first five hours of sleep (Table 2). From the control data of Howse et al.,27 children with chrono-

Table 1 Anthropometric and clinical details

\begin{tabular}{|c|c|c|c|c|c|c|c|c|c|c|c|c|c|c|}
\hline \multirow[t]{2}{*}{$\begin{array}{l}\text { Patie } \\
\text { no. }\end{array}$} & \multirow[t]{2}{*}{$\begin{array}{l}n t \\
\text { Sex }\end{array}$} & \multirow[t]{2}{*}{$\begin{array}{l}\text { Age } \\
(y r)\end{array}$} & \multirow[t]{2}{*}{$\begin{array}{l}\text { Bone } \\
\text { age (yr) }\end{array}$} & \multirow[t]{2}{*}{$\begin{array}{l}\text { Height } \\
(\mathrm{cm})\end{array}$} & \multirow[t]{2}{*}{$\begin{array}{l}\text { Weight } \\
(\mathrm{kg})\end{array}$} & \multirow[t]{2}{*}{$\begin{array}{l}\text { Puberty } \\
\text { stage } 22\end{array}$} & \multirow{2}{*}{$\begin{array}{l}\text { Growth } \\
\text { velocity } \\
(\mathrm{cm} / \mathrm{yr})\end{array}$} & \multirow{2}{*}{$\begin{array}{l}\text { Growth } \\
\text { velocity } \\
\text { expected } \\
\text { for bone } \\
\text { age } 28 \\
(\mathrm{~cm} / \mathrm{yr})\end{array}$} & \multirow{2}{*}{$\begin{array}{l}\text { Growth } \\
\text { rate as } \\
\% \text { of } \\
\text { predicted }\end{array}$} & \multirow[t]{2}{*}{$\begin{array}{l}\text { Clinical } \\
\text { presentation }\end{array}$} & \multirow{2}{*}{$\begin{array}{l}\text { Duration } \\
\text { of } \\
\text { symptoms } \\
(y r)\end{array}$} & \multicolumn{2}{|c|}{$\begin{array}{l}\text { Site of } \\
\text { involvement }\end{array}$} & \multirow{2}{*}{$\begin{array}{l}\text { Medication } \\
\text { at time of } \\
\text { study }\end{array}$} \\
\hline & & & & & & & & & & & & Ileum & Colon & \\
\hline 1 & $\mathbf{F}$ & $15 \cdot 1$ & $10 \cdot 0$ & 129 & $26 \cdot 1$ & I & 0.5 & $5 \cdot 4$ & $9 \cdot 3$ & Short stature & 3 & + & & Nil \\
\hline 2 & $\mathbf{M}$ & $14 \cdot 8$ & $12 \cdot 5$ & 140 & 33.4 & II & $2 \cdot 0$ & $5 \cdot 2$ & $38 \cdot 5$ & Short stature & 2 & + & + & Nil \\
\hline 3 & $\mathbf{M}$ & $13 \cdot 1$ & $11 \cdot 0$ & 136 & $30 \cdot 0$ & I & $1 \cdot 6$ & $5 \cdot 0$ & $32 \cdot 0$ & Diarrhoea & 3 & + & & Nil \\
\hline 4 & $\mathbf{M}$ & $20 \cdot 2$ & $15 \cdot 5$ & 155 & $44 \cdot 3$ & III & $2 \cdot 0$ & $4 \cdot 7$ & $42 \cdot 6$ & $\begin{array}{l}\text { Short stature } \\
\text { Perianal } \\
\text { disease }\end{array}$ & 1.5 & + & + & Nil \\
\hline 5 & $\mathrm{~F}$ & $13 \cdot 3$ & $9 \cdot 0$ & 143 & $33 \cdot 5$ & I & $1 \cdot 6$ & $5 \cdot 5$ & $29 \cdot 0$ & Diarrhoea & $1 \cdot 3$ & - & + & $\begin{array}{l}S Z P^{*} \\
3 \text { g/day }\end{array}$ \\
\hline
\end{tabular}

*SZP: sulphasalazine. 


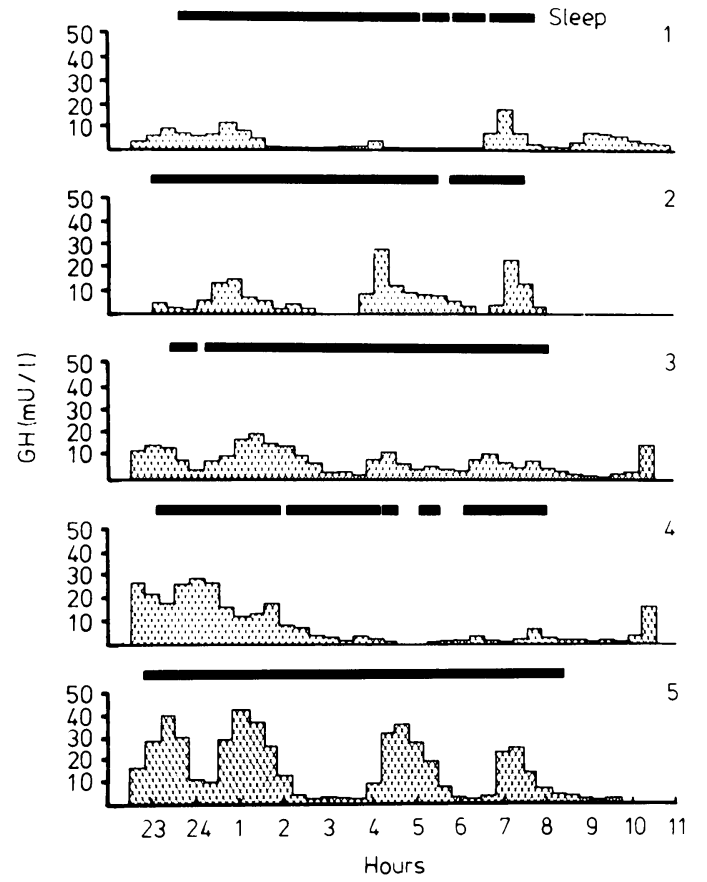

Fig. 1 Nocturnal growth hormone profiles in growth retarded children (patients 1-5) with Crohn's disease.

Table 2 Growth hormone secretion during sleep and insulin hypoglycaemia

\begin{tabular}{|c|c|c|c|c|}
\hline \multirow[t]{2}{*}{$\begin{array}{l}\text { Patient } \\
\text { no. }\end{array}$} & \multicolumn{2}{|c|}{$\begin{array}{l}\text { Nocturnal growth hormone } \\
(\mathrm{mU} / \mathrm{l})\end{array}$} & \multicolumn{2}{|c|}{$\begin{array}{l}\text { Insulin hypoglycaemia } \\
\text { growth hormone }(\mathrm{m} U \mathrm{l})\end{array}$} \\
\hline & $\begin{array}{l}\text { Sleep } \\
\text { 5 hour mean }\end{array}$ & $\begin{array}{l}\text { Sleep } \\
\text { peak }\end{array}$ & Basal & Peak \\
\hline 1 & $3 \cdot 8$ & $18 \cdot 1$ & $<1.0$ & $6 \cdot 4$ \\
\hline 2 & $5 \cdot 0$ & $28 \cdot 6$ & $3 \cdot 4$ & $22 \cdot 0$ \\
\hline 3 & 8.5 & 19.0 & 2.8 & $31 \cdot 0$ \\
\hline 4 & $14 \cdot 0$ & 29.7 & $<1.0$ & $40 \cdot 0$ \\
\hline 5 & 18.0 & $41 \cdot 7$ & $15 \cdot 0$ & 15.0 \\
\hline $\begin{array}{l}\text { Normal } \\
\text { values } 27\end{array}$ & $>10$ & $>29$ & & $>20$ \\
\hline
\end{tabular}

logical and bone ages similar to those in the present study had five hour mean growth hormone levels above $10 \mathrm{mU} / 1$. According to this criterion, patients 1 , 2 , and 3 have inadequate sleep growth hormone responses. Similarly, peak sleep growth hormone concentrations (Table 2) in these three patients were below those of normal short children of similar age. ${ }^{27}$

However, of these three patients, only patient 1 failed to demonstrate an adequate growth hormone response to insulin hypoglycaemia. Patient 5 also had an inadequate growth hormone response to insulin hypoglycaemia (Table 2), although sleep growth hormone response appeared to be normal.
GROWTH HORMONE AND GROWTH VELOCITY

The relationship between growth velocity and five hour mean growth hormone concentrations for each of the five patients is shown in Fig. 2. Five hour mean growth hormone response to sleep is not closely related
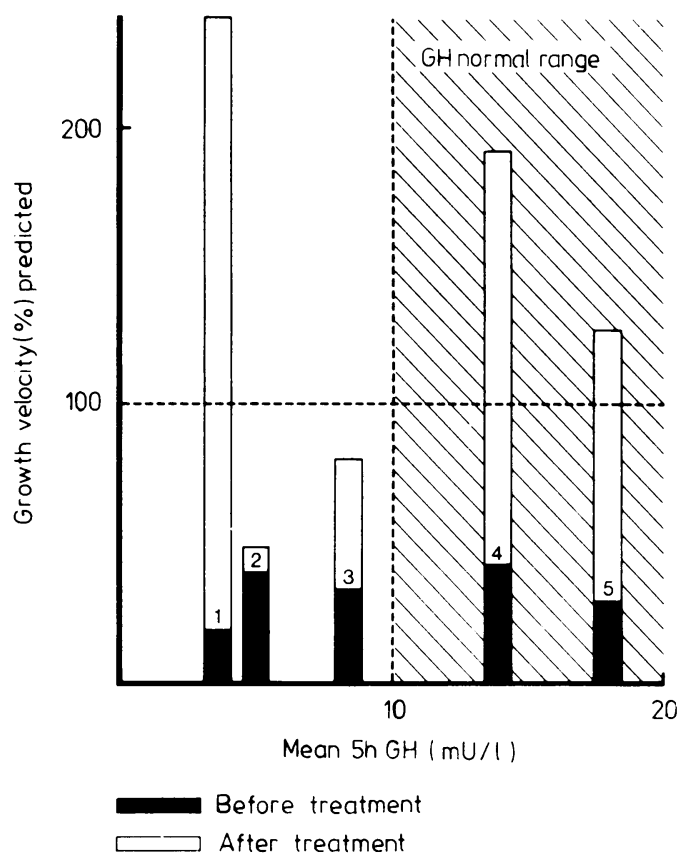

Fig. 2 Pre-treatment five hour mean growth hormone secretion during sleep and its relationship to growth velocit $y^{28}$ before and after treatment. Growth velocities of the individual patients (numbers 1-5, Table 1) are plotted according to the five hour mean growth hormone concentration shown on the horizontal axis. The hatched area represents the normal range for five hour mean growth hormone secretion in children and adolescents of similar ages. 27

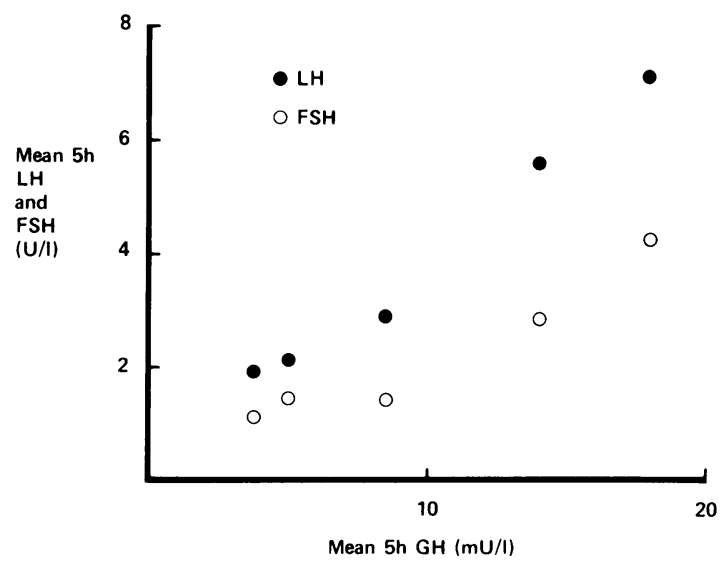

Fig. 3 The relationship between five hour mean growth hormone and gonadotrophin secretion during sleep. 
to growth velocity (plotted as a percentage of the expected growth velocity for bone age ${ }^{28}$ ) during the year before this study, nor to subsequent growth after treatment. The failure of the growth hormone response to sleep to predict future growth is particularly evident in patient 1 who had the lowest five hour mean growth hormone concentration but who had the most marked improvement in linear growth after treatment.

\section{GROWTH HORMONE AND GONADOTROPHINS}

Episodic secretion of luteinising hormone and follicle stimulating hormone was detectable only in patients 4 and 5 who had the highest five hour mean gonadotrophin levels. Figure 3 shows the highly significant linear relationship between five hour mean and growth hormone and five hour mean gonadotrophin levels in these patients with Crohn's disease (luteinising hormone, $r=0.99$; follicle stimulating hormone, $r=$ $0 \cdot 96, \mathrm{P}<0.01)$.

GROWTH HORMONE AND DISEASE ACTIVITY

There was a significant correlation between five hour mean growth hormone secretion and the Crohn's disease activity score determined at the time of the study $(r=0.79, \mathrm{P}<0.05)$.

\section{Discussion}

This study demonstrates that the growth hormone response to sleep and insulin hypoglycaemia is reduced in some growth retarded children with Crohn's disease. Although control data for plasma nocturnal growth hormone profiles and five hour mean growth hormone concentrations were derived from published work from another centre, 27 this was considered reasonable in view of the difficulties of performing such studies in healthy children, and as the continuous sampling technique and growth hormone assay standards were identical.

In contrast, rises in plasma growth hormone concentration during sleep in a total of 15 growth retarded children with Crohn's disease assessed by intermittent venous sampling were considered adequate.141517 However, the lowest acceptable sleep-related growth hormone concentration varied and decisions regarding normality in one study 14 would have been reversed in another, ${ }^{17}$ depending on which control data from the literature were used. In addition, Gotlin and Dubois ${ }^{17}$ failed to find a difference between diurnal and nocturnal plasma growth hormone concentration, an observation which would now be regarded as abnormal.

Although investigators using the growth hormone response to insulin hypoglycaemia have uniformly acknowledged the occurrence of inadequate growth hormone responses in growth retarded children with Crohn's disease, 6916 there is no obvious explanation for the discordance between the findings of the present study and earlier reports regarding sleep-related growth hormone secretion. However, the continuous sampling technique used in the present study is probably the most reliable method, as it produces a complete nocturnal growth hormone profile which permits detection of all sleep-related growth hormone peaks and therefore excludes false assignations of growth hormone insufficiency, an inherent disadvantage of the intermittent sampling methods. Previous reports, ${ }^{14} 1517$ unlike the present study, did not take into account the age-related changes that occur in nocturnal growth hormone secretion, 2729 a factor which may account for some of the discrepancies in the literature. Disagreement between the numerous pharmacological and physiological tests of growth hormone secretion is well recognised 30 and was confirmed by the present study when concordance between growth hormone responses to sleep and hypoglycaemia was reached in only two of the five subjects.

The relevance of diminished growth secretion to the impairment of linear growth in children and adolescents with Crohn's disease has not been answered by previous studies, although McCaffery et al. ${ }^{6}$ did not find abnormal growth hormone responses to hypoglycaemia in any of the control subjects with Crohn's disease who had grown normally. The present study failed to detect any obvious relationship between sleeprelated growth hormone secretion and growth velocity, indicating that impaired growth hormone secretion cannot be implicated directly in the growth retardation of children with Crohn's disease. There was, however, a striking relationship between five hour mean growth hormone levels and the Crohn's disease activity score in these growth retarded children with Crohn's disease, a finding which ideally should be confirmed in children with Crohn's disease who have developed normally. The severity of the disease has not been adequately stated in earlier assessments of growth hormone secretion in Crohn's disease and may have been an important factor contributing to the disparity between published findings. The importance of disease activity was emphasised by Green et al. ${ }^{9}$ who demonstrated the reversibility of abnormal growth hormone response to hypoglycaemia when the disease was in remission.

The close correlation between five hour mean growth hormone and five hour mean gonadotrophin concentrations suggest that, whatever inhibitory factors are operating, other aspects of hypothalmic-pituitary function are also involved. This finding is consistent with previous reports of reduced 24 hour urinary gonadotrophins in growth retarded children with Erohn's disease and restoration of normal plasma gonadotrophins when the disease was in remission. ${ }^{9}$

The mechanisms involved in the disturbance of growth hormone secretion in some growth retarded 
children with Crohn's disease remain a matter for speculation. The observation that impaired growth hormone secretion in response to hypoglycaemia also occurs in children with coeliac disease ${ }^{31} 32$ suggests ihat it is probably not disease specific. Although a strong case has been made to implicate calorie deprivation as an important cause of growth retardation in children with Crohn's disease, 1433 basal growth hormone concentrations are usually raised during starvation and protein-calorie malnutrition. ${ }^{34} 35$ For this reason, it was concluded that impairment of growth secretion in coeliac disease was unlikely to be due simply to malnutrition. ${ }^{31}$

However, raised basal growth hormone concentration has been reported in some children with Crohn's disease $^{9} 1517$ and was observed in one subject in the present study (patient 5 , Table 2 ). In addition, anterior pituitary function and growth hormone production in particular is impaired in malnourished experimental animals. ${ }^{36}{ }^{37}$ Finally, there is now considerable evidence of reduced catecholaminergic drive during semistarvation or fasting associated with reduction in tissue noradrenaline turnover. ${ }^{38}{ }^{39}$ Catecholamines are important facilitatory influences on the hypothalamicpituitary secretion of both growth hormone and the gonadotrophins 40 and it is possible that a reduced catecholaminergic drive due to calorie deprivation may partly explain the endocrine disturbance of childhood Crohn's disease and possibly coeliac disease. Although the present study has demonstrated an association between sleep-related growth hormone secretion and the severity of the Crohn's disease, disease activity and calorie deprivation are likely to be dependent variables.

MJGF gratefully acknowledges the support of The Wellcome Trust. The authors are also grateful for assistance from the Crohn's in Childhood Research Appeal (CICRA).

\section{References}

${ }^{1}$ Logan AH, Brown PW. Intestinal infantilism as a result of regional enteritis. Proc Mayo Clinic 1938; 13:335-6.

2Tanner NC. Dwarfism resulting from chronic regional enteritis. Proc Roy Soc Med 1939; 32:444-5.

${ }^{3}$ Crohn BB, Yunich AM. Ileojejunitis. Ann Surg 1941; 113 : 371-80.

${ }^{4}$ Silverman FN. Regional enteritis in children. Aust Paediatr J 1966; 2:207-17.

5 Winkelman EI. Regional enteritis in adolescence. Pediatr Clin N Am 1967; 14:141-58.

${ }_{6}$ McCaffrey TD, Nasr K, Lawrence AM, Kirsner JB. Severe growth retardation in children with inflammatory bowel disease. Pediatrics 1970; 45:386-93.

${ }^{7}$ Guttman FM. Granulomatous enterocolitis in childhood and adolescents. J Pediatr Surg 1974; 9:115-21.
${ }^{8}$ Harris BH, Hollabaugh RS, Clatworthy HW. Surgery for developmental and growth failure in childhood granulomatous enteritis. J. Pediatr Surg 1974; 9:301-4.

${ }^{9}$ Green JRB, O'Donoghue DP, Edwards CRW, Dawson AM. A case of apparent hypopituitarism complicating chronic inflammatory bowel disease in childhood and adolescence. Acta Paediatr Scand 1977; 66:643-7.

${ }^{10}$ O'Donoghue DP, Dawson AM. Crohn's disease in childhood. Arch Dis Childh 1977; 52:627-32.

${ }^{11}$ Homer DR, Grand RJ, Colodny AH. Growth, course and prognosis after surgery for Crohn's disease in children and adolescents. Paediatrics 1977; 59:717-25.

${ }^{12}$ Sobel EH, Silverman FN, Lee CM. Chronic regional enteritis and growth retardation. Am J Dis Child 1962; 103:569-76.

${ }^{13}$ Donald JW, Donald JG. Regional enteritis and growth retardation without intestinal symptoms. South Med J 1973;66:909-12.

${ }^{14}$ Kelts DG, Grand RJ, Shen G, Watkins JB, Werlin SL, Boehme C. Nutritional basis of growth failure in children and adolescents with Crohn's disease. Gastroenterology 1979; 76:720-7.

${ }^{15}$ Tenore A, Berman WF, Parks JS, Bongiovanni AM. Basal and stimulated growth hormone concentrations in inflammatory bowel disease. J Clin Endocr Metab 1977; 44: $622-28$.

${ }^{16}$ Kirschner BS, Thorp FK, Rosenfield RL, Roseberg IH. Endocrine studies in children with growth retardation due to Crohn's disease. Gastroenterology 1979; 76:1171. (Abstract).

${ }^{17}$ Gotlin RW, Dubois RS. Nyctohemeral growth hormone levels in children with growth retardation and inflammatory bowel disease. Gut 1973; 14:191-5.

${ }^{18}$ Takahashi Y, Kipnis DM, Daughaday WH. Growth hormone secretion during sleep. J Clin Invest 1968; 47 : 2079-90.

${ }^{19}$ Mace JW, Gotlin RW, Sassin JF, Parker DC, Rossman LG. Usefulness of post-sleep human growth hormone release as a test of physiologic growth hormone secretion. J Clin Endocr Metab 1970; $31: 225-6$.

${ }^{20}$ Mace JW, Gotlin RW, Beck P. Sleep-related human growth hormone $(\mathrm{GH})$ release: test of physiologic growth hormone secretion in children. J Clin Endocr 1972; 34: $339-41$.

${ }^{21}$ Schachter H, Kirsner JB. Definition of inflammatory bowel disease of unknown aetiology. Gastroenterology 1975; 68:591-600.

22Tanner JM. Growth at adolescence. Oxford: Blackwell. 1955.

${ }^{23}$ Greulich WW, Eyle SI. Radiographic atlas of skeletal development of the hand and wrist. California: Stanford University Press, 1959.

${ }^{24}$ Willoughby JMT, Kumar PJ, Beckett J, Dawson AM. Controlled trial of azathioprine in Crohn's disease. Lancet 1971:2:944-7.

${ }^{2 \varsigma}$ Farthing MJG. Mattei AM. A new cannula for intermittent and continuous venous sampling without heparinisation. Br Med J 1979; 2:1112.

${ }^{26}$ Hall R, Anderson J, Smart GA, Besser GM. Fundamentals in clinical endocrinology. London: Pitman Medical. 1974.

${ }^{27}$ Howse PM. Rayner PHW. Williams JW. Rudd BT, 
Bertrande PV, Thompson CRS, Jones LA. Nyctohemeral secretion of growth hormone in normal children of short stature and in children with hypopituitarism and intrauterine growth retardation. Clin Endocr 1977; 6:347-359.

28Tanner JM, Whitehouse RH, Takaishi M. Standards from

birth to maturity for height, weight, height velocity and weight velocity: British children, 1965, Part II. Arch Dis Childh 1966; 41:613-35.

${ }^{29}$ Finkelstein JW, Roffwarg HP, Boyar RM, Kream J, Hellman L. Age-related change in the twenty-four hour spontaneous secretion of growth hormone. J Clin Endocr Metab 1972; 35:665-670.

${ }^{30}$ Frasier SD. A review of growth hormone stimulation tests in children. Pediatrics 1974; 53:929-37.

${ }^{31}$ Day G, Cvans K, Wharton B. Abnormalities of insulin and growth hormone secretion in children with coeliac disease. Arch Dis Childh 1973; 48:41-46.

32Vanderschueren-Lodeweyckx M, Wolter R, Molla A, Eggermont E, Eeckels R. Plasama growth hormone in coeliac disease. Helv Paediat Acta 1973; 28:349-57.

${ }^{33}$ Layden T, Rosenberg J, Nemchausky B, Elson C, Rosen- berg I. Reversal of growth arrest in adolescents with Crohn's disease after parenteral alimentation. Gastroenterology 1976; 70:1017-21.

${ }^{34}$ Pimstone BL, Barbezat G, Hansen JDL, Murray P. Studies on growth hormone secretion in protein-calorie malnutrition. Am J Clin Nutr 1968; 21 :482-7.

${ }^{35}$ Kipnis DM, Hertelendy F, Machlan LJ. Progress in endocrinology. Amsterdam: Excerpta Medica, 1969: 601.

${ }^{36}$ Srebnik HH, Nelson MM. Anterior pituitary function in male rats deprived of dietary protein. Endocrinology 1962; 70:723-730.

${ }^{37}$ Meites J, Fiel NJ. Effect of starvation of hypothalamic content of 'somatotrophin releasing factor' and pituitary growth hormone content. Endocrinology 1965; 77:455-460.

${ }^{38}$ Young JB, Landsberg L. Suppression of sympathetic nervous system during fasting. Science 1977; 196:1473-5.

${ }^{39}$ Young JB, Landsberg L. Effect of diet and cold exposure on norepinephrine turnover in pancreas and liver. $\mathrm{Am} J$ Physiol 1979; 236:E524-E33.

40Martin JB. Neural regulation of growth hormone secretion. N Engl J Med 1973; 288:1384-93. 


\section{Books}

Rational Diagnosis and Treatment: An Introduction to Clinical Decision Making Second edition By Henrik R Wulff. (Pp. 209. Illustrated. £7.25.) Blackwell Scientific: Oxford. 1981.

The scope of this important book is much wider than its title suggests. As well as being an introduction to the process of medical decision making it also sets out to cover its logic (in 'new' mathematical terminology) and to provide an introduction to the ethics of investigation and treatment and the appreciation of the design and presentation of medical papers.

Dr Wulff is a gastroenterologist, and many of the examples which he quotes are drawn from the specialty. This is fitting, as it has at least its share of the problems attendant on costly technology, shaky taxonomy of disease, and the introduction of new drugs on arguable statistical evidence. Inevitably, a wide range is sometimes attained at the expense of superficiality, and I found myself wanting a fuller discussion of many of the subjects which were touched upon and then dropped, notably the potential conflict between a narrow duty to one's patient and a broader one to those who pay or may compete for the resources used. The management of Crohn's disease, as illustrating the problems posed by a syndrome which may not be homogeneous, also deserved a less dismissive and, I thought, more sympathetic approach than it received.

Many people have been grateful to the first edition as their source of the professional selfinquiry needed to meet the criticisms of Illich or Kennedy, and the second deserves even wider recognition as the classic it is. I had had the privilege of reviewing the first edition, and renewed my pleasure in the author's humour and choice of literary allusion: it was particularly pleasing to find that my favourites, the evolution of the bill of the ibis and the disputed definition of a triple-blind trial, were still there.

PETER BALL

\section{Notes}

Endoscopy Teaching Meeting

The BSG Endoscopy Teaching Meeting 1982

will take place at the Robin Brook Centre, St.

Bartholomew's Hospital, London from 22-

24 April. There will be separate courses of instruction for beginner endoscopists, more experienced endoscopists, and for nurses and endoscopy assistants. Details and application forms may be obtained from The Postgraduate Secretary, The Robin Brook Centre, St. Bartholomew's Hospital, London EC1.

\section{Correction}

Nocturnal growth hormone and gonadotrophin secretion in growth retarded children with Crohn's disease by M J G Farthing, C A Campbell, J Walter-Smith, C R Edwards, L A Rees, and A N Dawson. Gut 1981; 22:933
We regret the printing errors in the first seven lines of the summary of this paper and print the correct lines below. A loose gummed slip to paste over the incorrect summary is also included in this issue.

SUMMARY Although impaired growth hormone secretion in reponse to pharmacological stimuli occurs in some growth retarded children with Crohn's disease, its relationship to past and future growth is uncertain. We have therefore determined the growth hormone and gonadotrophin response to the physiological stimulus of sleep by continuous venous sampling in five severely growth retarded children with Crohn's disease. From the complete nocturnal growth hormone and gonadotrophin profiles, the mean plasma hormone concentrations during the first five hours of sleep were determined. In three of the five patients, five hour mean growth hormone levels were 
SUMMARY Although impaired growth hormone secretion in response to pharmacological stimuli occurs in some growth retarded children with Crohn's disease, its relationship to past and future growth is uncertain. We have therefore determined the growth hormone and gonadotrophin response to the physiological stimulus of sleep by continuous venous sampling in five severely growth retarded children with Crohn's disease. From the complete nocturnal growth hormone and gonadotrophin profiles, the mean plasma hormone concentrations during the first five hours of sleep were determined. In three of the five patients, five hour mean growth hormone levels were reduced $(3 \cdot 8$, 5.0 , and $8.5 \mathrm{mU} / \mathrm{l})$ compared with levels reported previously in normal short children $(10-43 \mathrm{mU} / \mathrm{l})$, although the pulsatile pattern of growth hormone secretion was preserved in all. Nocturnal growth hormone secretion was unrelated to the growth velocities of these children during both pre and post-treatment assessment periods but a significant correlation was found between growth hormone concentration and a disease activity score $(r=0.79, \mathrm{P}<0.05)$, suggesting that growth hormone release by the pituitary was influenced by the severity of the disease. Nocturnal growth hormone secretion was also correlated with gonadotrophin secretion (luteinising hormone, $r=0.99$, and follicle stimulating hormone, $r=0.96 ; \mathrm{P}<0.01$ ) indicating more extensive hypothalamic-pituitary disturbance. These findings suggest that hypothalamic-pituitary function is depressed in growth retarded children with Crohn's disease, but that abnormalities of growth hormone secretion are unlikely to be directly involved in the growth retardation seen in this condition. 